\title{
DEVELOPMENT OF VILLAGE PROFILE AS THE VILLAGE DEVELOPMENT PLANNING INPUT IN TARAI BANGUN VILLAGE TAMBANG DISTRICT KAMPAR REGENCY
}

\author{
Sulaiman Zuhdi, Prihati, Aguswan \\ Universitas Lancang Kuning \\ e-mail: sulaiman@unilak.ac.id
}

\begin{abstract}
purpose of this study was to determine and analyze the ability of village apparatus in compiling village profiles and utilizing village profiles in village development planning. This research is descriptive analysis with a qualitative approach. The results showed that the profile of Tarai Bangun village had not been arranged accurately, actual and comprehensively because in filling out the village profile it had not fully used the correct data sources and procedures. This is inseparable from the low level of village apparatus capacity and lack of community participation and the lack of budget used in collecting village profile data. Furthermore, in utilizing village profile data which is expected to be used as a baseline with village development actors in supporting planning, organizing, implementing, controlling, evaluating and policies, programs and activities in Tarai Bangun village, it cannot be realized. Another obstacle is the lack of attention of the regional government in collecting village profiles so that the use of village profile data cannot be used as inputs or sources of information in village development planning. Therefore, there is a need for local government policies to improve the knowledge and skills of village officials through the provision of training and training or assistance in filling out village profiles in accordance with the format of the Minister of Home Affairs Regulation No. 12 of 2007.
\end{abstract}

Keywords: capability, village apparatus, village profile

Tujuan penelitian ini adalah untuk menentukan dan menganalisis kemampuan aparatur desa dan desa yang memanfaatkan profil desa dalam perencanaan pembangunan desa. Penelitian ini merupakan penelitian deskriptif dengan pendekatan kualitatif. Hasil penelitian menunjukkan bahwa profil Tarai membangun desa belum tersusun secara akurat, aktual dan komprehensif karena tidak sepenuhnya menggunakan sumber dan prosedur data yang benar. Hal ini tidak terlepas dari rendahnya kapasitas aparat desa dan kurangnya partisipasi masyarakat dan kurangnya anggaran yang digunakan dalam mengumpulkan data profil desa. Selain itu, dalam memanfaatkan data profil desa yang diharapkan dapat digunakan sebagai baseline dengan aktor pembangunan desa, melaksanakan, mengendalikan, mengevaluasi dan mengevaluasi kebijakan, program dan kegiatan di Tarai Membangun desa, itu tidak dapat direalisasikan. Kendala lain adalah kurangnya perhatian pemerintah daerah untuk mengumpulkan desa yang dapat digunakan sebagai informasi dalam perencanaan pembangunan desa. Oleh karena itu, ada kebutuhan untuk kebijakan pemerintah daerah untuk meningkatkan pengetahuan dan keterampilan para pejabat melalui penyediaan pelatihan dan pelatihan. 12 tahun 2007.

Kata Kunci : kapabilitas, perangkat desa, profil desa.

\section{PENDAHULUAN}

birth of Law No. 22 of 1999 which was enhanced by Law No. 32 of 2004 concerning regional autonomy, the opportunity was opened to formulate a village development planning program that could reach all levels of society according to the needs and desires of the community. Therefore, in the 
preparation of village development planning, accurate data and information about the conditions of the village are needed.

Accurate and accountable data and information is one of the important elements in village development planning. Sources of information in collecting village profile data are family heads, RT administrators, RW administrators, hamlet heads, neighborhood heads, village heads, village heads and village officials, TP-PKK administrators and community institutions as well as technical implementation units. in villages and sub-districts.

In connection with this matter, the Ministry of Home Affairs issued Regulation of the Minister of Home Affairs No. 12 of 2007 concerning Guidelines for the Formulation and Utilization of Data on Village and Village Profile. In this Regulation of the Minister of Home Affairs regulated mechanisms and instruments that become references in the preparation of a village data base. In general, the preparation of village and sub district profile data includes activities such as:

1. Preparation of data collection instruments

2. Preparation of working groups profile of villages and villages

3. Implementation of data collection Data

4. processing

5. Publication of village and sub district profile data.

Furthermore, in utilizing village and sub district profile data, it is directed at the use of data as basic data with village and urban development actors in supporting planning, organizing, implementing, controlling, evaluating and preserving policies, programs and activities for poverty alleviation, community empowerment, public services, coaching and supervising the administration of village and sub district government, social institutions and the administration of government administrative areas.

Thus, the basic data is expected to describe fully the characteristics of the village and can be used as inputs(input)in rural development planning.

The substance of the village profile includes 3 (three) things, namely:

1. Basic family data, namely data containing family profiles which include data on human resources (HR), economic and social assets, quality of life in the fields of health, economy and education as well as participation as citizens, members of community institutions and various family and social welfare issues that are real happens in every family. The basic data of this family is to provide a data base on the quality of life of Indonesian people at the family level, RT, RW, Dusun and Lingkungan. Through this data it is expected that the preparation of the Indonesian Human Development Index (HDI) can be measured by valid and reliable data and reaching everyone in each family.

2. Data on the potential of the village / sub district, including all the potential that the village has, namely: natural resources, human resources, institutional resources and resources of infrastructure and facilities. The existence of this potential data will be known typologies from each village and the potential to be developed.

3. Data on the level of development of the village / sub district, contains the level of success of the village development activities carried out for one year and for five years. From the results of evaluating the success of development activities for one year, the status of village development will be obtained.

While the usefulness of village profile preparation is as follows:

1. Support various government policies

2. Assist the implementation of regional and village autonomy

3. Help the private sector to participate in village development

4. For the basis of consideration of the village development budget

5. Determination of development priority areas in the village. 
In making village development planning, it is necessary to understand the village by analyzing the village situation so that it looks at the village profile / portrait that shows the physical / geographical, socio-economic, socio-cultural, environmental conditions, village problems, village potentials and opportunities and challenges ( Hanif Nurcholis, 2009, p. 10)

Judging from the condition of the village Tarai Bangun in village development planning has not described the needs and problems of the village. This means that from the conditions there are still many village development hopes that have not been realized. This is not separated from yet availability of accurate and actual village profile data. Accurate and actual village profile data cannot be separated from the ability of the village apparatus in registering village potential. The ability and skills of the Tarai Bangun village apparatus in reality are still far from expectations. This is inseparable from lack of knowledge of human resources, ineffective institutional functions, low community participation and lack of budget in preparing village profiles.

The limited ability of the village apparatus both in quality and quantity greatly affects the ability to carry out the tasks of the village government. One of the tasks of the village government is data collection and village profiling. The task of collecting and profiling villages is a task that requires its own knowledge and skills from the village apparatus.

While the ability of the village apparatus is still weak, it is natural that the village profile has not been properly and accurately arranged and can be used as a source of information in the development plan in Tarai Bangun village.

This study aims to find out and analyze the ability of the village apparatus in the formulation of village profiles and the utilization of village profiles in village development plans.

\section{METODE}

This study used a qualitative descriptive method. The use of qualitative methods is carried out through observation, interviews or interviews and literature studies (Library Search), which takes data from a number of books, literature, the internet, and legislation. In analyzing the data and information obtained, the authors take steps to reduce data, data classification and data processing qualitatively. In this stage each data is given an understanding so that it is easy to understand to get the final conclusion.

\section{HASIL DAN PEMBAHASAN}

A. The ability of the village apparatus

The Tarai Bangun village was an expansion village from the main village, Kualu village. In the beginning the Tarai Bangun village was a territory which was divided into 2 (two) regions, namely the hamlet IV Tarai and Dusun V Rawa Bangun. Along with regional development and population growth, in 2002 a village (Preparation) was born Tarai Bangun. At present the Tarai Bangun village already has village profile data in the form of books and blackboards that are hung in the village office room and cannot be accessed through the village web. For village data written on the blackboard, it is still a village monograph, the village monograph format still uses the old format and until now has not been adapted to the new format.

From the results of interviews with Eka Putra informants as the village secretary of Tarai Bangun who stated that filling in the village monograph, the potential of the village and village profiles were carried out annually based on the previous year's data estimates. The correct data should be filled in by directly collecting data on the homes of the residents by involving RT, RW, hamlet heads, neighborhood 
heads, village heads, village officials, PKK TP administrators and community institutions as well as the technical unit of the regional and central work units in villages and sub-districts, so that the accuracy of the data can be obtained. Village apparatus are still having difficulties in filling out village profile data in accordance with the Minister of Home Affairs Regulation No. 12 of 2007 because they are considered too complicated, so that many village profile data have not been filled completely and are still not perfect.

Based on the Minister of Home Affairs Regulation No. 12 of 2007, where village profile data consists of:

1. Basic family data, namely data containing family profiles which include data on human resources (HR), economic and social assets, quality of life in the health, economy and education and participation as citizens, members of community institutions and various family and social welfare issues that actually occur in each family are included in the village profile but are not yet fully filled and accurate because the data are not obtained from the field data collection, but based on estimates and previous year data.

2. Data on the potential of the village / sub district, including all the potential possessed by the village, namely: natural resources, human resources, institutional resources and resources of infrastructure and facilities already contained in the village profile but not yet fully filled and accurate because the data were not obtained from the results of field data collection, but based on previous year's estimates and data.

3. Data on the level of village development, containing the success rate of village development activities carried out for one year and for five years already contained in the village profile but not all development activities have been filled and accurate because there are still development results that have not been properly recorded.

The problems faced in compiling the village profile include:

1. Lack of knowledge and skills of the village apparatus, this can be seen from the level of education of the village apparatus, the majority of whom are high school educated and some are only elementary school graduates.

2. Village administrations have not involved relevant elements in the village such as RT, RW, hamlet heads, neighborhood heads, PKK TP administrators and community organizations to collect village profiles.

3. Lack of budget allocated for data collection, village governments have not specifically allocated village funds to data collection activities.

4. Lack of community participation, the community is not involved in the village development planning process.

Considering the problems mentioned above, the important solution that must be done is empowering the village apparatus by increasing the capacity of the village government apparatus in developing village profiles through providing assistance and training in formulating village profiles, in addition to strengthening community and institutional participation and other aspects. . This is very important, because a well-structured village profile can be used as input or source of information needed in the village development planning process.

Abilities related to tasks and work are the ability of a person to carry out the work seriously and provide good results. Ability is the skill, knowledge, and mental work of someone who is supported by good physical conditions. Judging from the knowledge, skills, work experience, mental and physical conditions, the ability of the village apparatus responsible for filling out the village profile has not been fully able to carry out the tasks and work properly. Here the role of the district government is needed to facilitate the village apparatus to improve their capabilities through training and seminars on ways to survey / collect village profiles (such as observation, interview and recording techniques) and if necessary also provide opportunities for village officials to continue their studies more high. 
2. Utilizing village profiles in village development plans.

Accurate and accountable data and information in the compilation of village profile data is an important element as input in village development planning. Utilization of village profile data is directed at the use of data as basic data with village development actors in supporting planning, organizing, implementing, controlling, evaluating and preserving policies, poverty reduction programs and activities, community empowerment, public services, coaching and supervision of village administration, institutions community and administration of the village administration area. Thus, this basic data is expected to be able to describe in full the characteristics of the village, and of course also want to encourage the Regional Government and Village Government to make the data as a necessity in development planning.

From the results of interviews with informant Eka Putra as the village secretary of Tarai Bangun who stated that the existing village profile data had not been fully utilized or utilized in development policy planning or in the public interest of information users because the data were incomplete. This is because the village profile data does not yet reflect the actual condition of the village, thus it cannot function as a source of information on the village's potential.

Judging from existing village profile data, it can be explained that:

1. Basic family data, namely data containing various information about the population based on age, gender, level of education, religion, nationality, ethnicity, type of work and labor, quality of the workforce until information about mental and physical disability conditions already exists and can be used as information for preparing village development planning in terms of planning in the education and labor sectors. In the education sector, it can be seen the number of people who never attended school, did not complete elementary school, graduated from junior high school, graduated from high school and undergraduate. Regarding labor information is also illustrated about the type of work and the quality of the workforce. So a development program can be developed which basically aims to open up jobs that can absorb labor with various skills and expertise.

2. Village potential data, covering all the potential of the village, namely: natural resources, human resources, institutional resources and infrastructure and facilities resources. The natural resource data contained in the village profile provides various information about the area according to its use such as settlements, rice fields, plantations, offices, public infrastructure, climate, type and soil fertility, topography, agriculture, plantations, forestry, livestock and fisheries. Information on the economic potential derived from natural resources can be arranged in several development sectors including agriculture, plantation, forestry, livestock, fisheries and mining. Institutional information is obtained from institutional forms in the village such as LPM, PKK, Posyandu, Recitation, Savings and Loans, Farmers' Groups, Gapoktan, Karang Taruna and Ormas / NGOs. Likewise with facilities and infrastructure both educational, religious and social facilities can already be used as information in the village development planning process but not so accurate.

3. Data on the level of village development, containing the success rate of village development activities carried out for one year and for five years already contained in the village profile but not all development activities have been filled and accurate because there are still development results that have not been properly recorded. Information about the level of village development has not been accurately and comprehensively measured, so the level of village development is not yet known whether it is categorized as a fast-developing, developing, slow-growing and under-developed village.

Seeing the importance of utilizing village profiles in providing accurate and comprehensive sources of information and data in accordance with the facts as a reference for village development planning, the role of local government is needed to facilitate the formulation and utilization of village profiles through training and training activities as well as assistance to village officials in filling out profile data village. 


\section{KESIMPULAN}

Proper and targeted development planning in the village is very dependent on accurate and actual village profile data. The village profile should be able to clearly describe the real and overall condition of the basic family data, village potential and the level of village development. Problems in the preparation of village profiles are the low capacity of the village apparatus in filling out village profile data, lack of community participation and the lack of budget allocated for collecting village profile data. Then in the utilization of village profile data which is expected to be used as a baseline with village development actors in supporting planning, organizing, implementing, controlling, evaluating and policies, programs and activities in Tarai Bangun village, it cannot be realized. Another obstacle is the lack of attention of the regional government in collecting village profiles so that the use of village profile data cannot be used as inputs or sources of information in village development planning. Therefore, it is necessary for the role of local government in making policies to improve the knowledge and skills of village officials through the provision of training and training or assistance in filling village profiles in accordance with the format of Minister of Home Affairs Regulation No. 12 of 2007.

\section{DAFTAR PUSTAKA}

[1] Aguswan \& Zuhdi, S. (2018). Pemetaan Data Dan Informasi Penyusunan Perencanaan Pembangun Desa Di Kecamatan Tambang Kabupaten Kampar. Jurnal Niara, 11(1), 26-34. Https://Doi.Org/10.31849/Nia.V11i1.1522

[2] Dailiati, S., \& Saputra, T. (2018, May). Rising Pendapatan Asli Daerah (PAD) in Pekanbaru: Billboard Planning Policy Tax. In IOP Conference Series: Earth and Environmental Science (Vol. 156, No. 1, p. 012032). IOP Publishing.

[3] Hanif Nurcholis, 2011, Pertumbuhan dan Penyelenggaraan Pemerintahan Desa, Airlangga, Jakarta

[4] Hanif Nurcholis, 2008, Perencaaan Partisipatif Pemerintahan Daerah, Grasindo, Jakarta

[5] Hasibuan, Melayu S.P. (2007), Manajemen Sumber Daya Manusia, Jakarta. Bumi Aksara, Cetakan Ke Sembilan.

[6] K. Suhendra, 2011, Peran Birokrasi dalam Pemberdayaan Masyarakat, Alphabeta, Bandung

[7] Riant Nugroho, 2011, Manajemen Perencanaan Pembangunan, Gramedia, Jakarta

[8] UU No. 6 tahun 2014, Tentang Desa, Rona Publishing, Surabaya

[9] Undang-undang Nomor 32 Tahun 2004 tentang Pemerintahan Daerah

[10] Peraturan Pemerintah Republik Indonesia No 72 Tahun 2005 tentang Desa

[11] Utami, B. C., \& Saputra, T. (2018, May). Needs Analysis of Employee in Riau Main Island: A Reflection from Universitas Lancang Kuning Context. In IOP Conference Series: Earth and Environmental Science (Vol. 156, No. 1, p. 012057). IOP Publishing. 
[12] Permendagri Nomor 12 Tahun 2007 tentang Pedoman Penyusunan dan Pendayagunaan Data Profil Desa dan Sub district

[13] Peraturan pelaksana Pemerintahan Daerah, 2006, Eko Jaya, Jakarta

[14] Himpunan Petunjuk Pelaksanaan Desa/Sub district,2008, Fokusindo, Bandung

[15] Rancangan Awal RPJMD Propinsi Riau 2014-2019, Pekanbaru, Bappeda Propinsi Riau, Pekanbaru

[16] Rencana Strategis 2014-2019, Badan Perencanaan Pembangunan Daerah (BAPPEDA) Propinsi Riau, Pekanbaru

[17] Saputra, T., \& Sufi, W. (2018). Strategi Dalam Memberikan Pelayanan Kepada Masyarakat. Jurnal Benefita: Ekonomi Pembangunan, Manajemen Bisnis Dan Akuntansi, 3(3), 396-416.

[18] Sufi, W., \& Saputra, T. (2017). Implementation Of Village Empower Program In Supporting Form Of Institutions Of Village Business Institutions (Bumdes)(Study On Dayang Suri Village Bungaraya Sub District Siak Regency Riau Province). Jurnal Perspektif Pembiayaan Dan Pembangunan Daerah, 5(2), 91-98. 